\title{
Spiritual and Material Conversion in the Alchemical Work of Zosimus of Panopolis
}

\author{
Athanasios Rinotas
}

check for updates

Citation: Rinotas, Athanasios. 2021. Spiritual and Material Conversion in the Alchemical Work of Zosimus of Panopolis. Religions 12: 1008. https://doi.org/10.3390/rel12111008

Academic Editors: Eva Anagnostou, Georgios Steiris and Georgios Arabatzis

Received: 25 August 2021

Accepted: 2 November 2021

Published: 16 November 2021

Publisher's Note: MDPI stays neutral with regard to jurisdictional claims in published maps and institutional affiliations.

Copyright: (C) 2021 by the author. Licensee MDPI, Basel, Switzerland. This article is an open access article distributed under the terms and conditions of the Creative Commons Attribution (CC BY) license (https:// creativecommons.org/licenses/by/ $4.0 /)$.
De Wulf-Mansion Centre for Ancient, Medieval and Renaissance Philosophy, KU Leuven, 3000 Leuven, Belgium; athanasios.rinotas@kuleuven.be

\begin{abstract}
Zosimus of Panopolis was a Graeco-Egyptian alchemist of the 3rd century whose alchemy was imbued with both technical and Gnostic elements. In this way, the notion of conversion is met in the corpus of Zosimus in both its material and spiritual aspects. The aim of this paper is to present these two kinds of conversion by having a special focus on the role of the spirit (pneuma) in their procedures. Hence, in the first part of the study I present how pneuma is involved in the conversion of metals, while in the second I deal with the spiritual-Gnostic aspects of his alchemy, which pertain to the notion of the "divine spark." In the last part of the study, I examine the relation between pneuma and divine water in the work of Zosimus, which serves in turn as an exegetical tool for the Coptic-Gnostic source which is found in the Gospel According to Philip (61, 12b-20a).
\end{abstract}

Keywords: Zosimus of Panopolis; alchemy; Gnosticism; pneuma (spirit); metallic and spiritual conversion

\section{Introduction}

It was in the Hellenistic era that Greek thought made a turn to the 'irrational' with new forms of knowledge emerging purporting to attain the notion of the transcendent (Dodds 1984). Among these novelties, one may come across Graeco-Egyptian or Egyptian or Greek alchemy. ${ }^{1}$ Deficient as they may be in their descriptive purposes, these categorizations of alchemy still, through this deficiency, echo the great deal of syncretism that took place during that era. Nevertheless, current modern scholarship has abandoned the conviction that Graeco-Egyptian alchemy was the 'child of Greek philosophy' alone (Hopkins 1934), since interdisciplinary research has brought to light the abundance of influences from various sources, such as Hermeticism, Gnosticism and Egyptian metallurgy. ${ }^{2}$ Indeed, we have significant evidence that the artisans of Egypt had been working with gold, silver and precious stones for many centuries, whereas similar techniques of distillation, fermentation and cupellation were performed in Assyria, Babylon and Phoenicia as well. In addition, the Egyptian priests seemed to have been active in the process of adorning the temples; therefore, one can plausibly claim that they had somehow acquired experience in metallurgy and in processing metals, thus developing a strong background concerning alchemical arts. ${ }^{3}$

Leaving the historical roots of Graeco-Egyptian alchemy behind and returning to its Roman days, one may discern two integral aims of the art: (a) the transmutation of base metals into gold or silver and (b) the perfection and salvation of the soul and its ascent to the divine (Sheppard 1957, p. 87). With respect to the first aim, the notion of transmutation seems to be quite problematic and ambiguous, mostly because it is not clear whether by

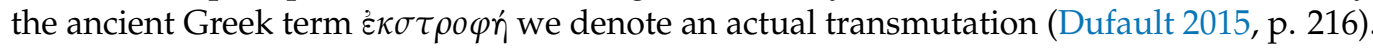
Likewise, the second aim is encumbered with Hermetic and Gnostic doctrines, which both tend to tamper with alchemy and connote a more spiritual kind of alchemy, divergent from its purely practical aspects. ${ }^{4}$ It is in this milieu that the personage of Zosimus of Panopolis emerges. His alchemy comprises all the elements that have already been mentioned and 
thus this makes the interpretation of his alchemy a challenging task. The aim of this paper is to bring these seemingly different versions of Zosimus' alchemy together by giving an account of the notion of conversion and how it relates to the spirit (pneuma). To explain myself, I treat the notion of conversion in its broader context; thus, I firstly deal with the notion of material conversion, which is concerned with the practical aspect of Zosimus' alchemy and the role of pneuma in it. Then, I delve into the spiritual aspect of conversion in Zosimus' alchemy, which is imbued with Gnostic and Hermetic elements and which is mostly concerned with the notion of the "pneumatic man" and his effort to ascend to the divine. In the last part of this paper, I make an attempt to create a liaison between the two types of Zosimean conversion by showing how his notion of divine water as well as the one of pneuma involved in it can act as a bonding factor between the practical and spiritual alchemy of Zosimus. To this end, I will employ the Zosimean alchemy as an exegetical tool in order to interpret the Coptic-Gnostic source of (61. 12b-20a), which is found in the Gospel According to Philip. This Coptic-Gnostic source deals with the topic of "baptism", which is also found in Zosimus and therefore Zosimus could be regarded as a "proper" exegetical tool for the aforementioned source. ${ }^{5}$ The last part of this paper should be regarded as a follow up of the studies of R. Charron-L. Painchaud and Viano, since I rely heavily on their work and provide further evidence that strengthens their initial claims concerning the relation between Graeco-Egyptian alchemy and Gnosticism. ${ }^{6}$

\section{Material Conversion in Zosimus of Panopolis' Alchemy}

Zosimus was born in Panopolis, which is located in Egypt, and he was active during the end of the third and the beginning of the fourth centuries AD. ${ }^{7}$ Undoubtedly, he has an eminent place in the history of ancient Greek alchemy, and he was supposed to have written a great deal of works of which only a small amount is left to us. ${ }^{8}$ His extant text has been divided into four groups: (a) Authentic Memoirs, (b) Chapters to Eusebia, (c) Chapters to Theodore, and (d) The Final Count and the two books of Sophe. All of these four groups of texts contain recipes for processing metals and accounts involving Gnostic and Hermetic elements. ${ }^{9}$ As De Jong stresses, in order for Zosimus' alchemy to work, there are certain conditions which need to be met. In particular, the alchemist should be equipped with perfect technical equipment, while he should also be mentally purified, so as to receive true knowledge, that is, Gnosis (De Jong 2006, p. 1185). Additionally, in his work, Zosimus addresses a certain Theosebeia, who was probably either a sister or a disciple of his. ${ }^{10}$ The possibility of Theosebeia being a disciple of Zosimus is further suggested by the fact that we meet instances in his work where he is concerned with the notion of initiation to mysteries. ${ }^{11}$ Finally, Zosimus acknowledges that demons may interfere in alchemical procedures, only that their interference results in a kind of alchemy that is deceitful; therefore for the true alchemical procedure to work there must be no demonic intervention (Principe 2013, p. 20).

Before turning to Zosimus' actual notion of material conversion and how it relates to pneuma, it would be appropriate to first provide some general information on the ancient Greek alchemical theory of transmutation. Recently, Dufault has challenged the proposition that the ancient Greek alchemists had a solid and well-defined theory of transmutation (Dufault 2015, pp. 215-44, esp. 216-17). Yet, one may come up with a general theory whose tenets can be applied to the group of the Graeco-Egyptian alchemists (Pseudo Democritus and Zosimus), which extends from 1st to 3rd CE (Merianos 2017, pp. 235-36; Martelli 2016, pp. 219-27). To begin with, Graeco-Egyptian alchemists believed there was a common matter to all metals, and thus the transformation of one metal to another was possible on the grounds that "all is one." For a metal to be converted, it should first be reduced to its prime matter, and then applied to an active principle, usually a volatile agent, which would bestow qualities on the metal. In more concrete terms, the alchemists distinguished between metallic bodies (sômata) and incorporeal ones (asômata). The former were usually the four fixed bodies-lead, tin, copper and iron - which served as the substrate (hupostata) of transmutation. ${ }^{12}$ Congruently, the incorporeal bodies were volatile vapours-that is, 
sublimates of sulphur and arsenic, etc. —which were responsible for endowing metals with qualities. These volatile agents were also named as "tinctures" from the ancient Greek word baphai ( $\left.\beta \alpha \varphi \alpha^{i}\right)$ (Fraser 2018, p. 728).

Turning now to Zosimus, one can find the aforementioned alchemical scheme in his work. Particularly, as Principe has already noticed, Zosimus distinguishes between a non-volatile fixed body which he calls "body" (sôma) and a volatile one which he calls "spirit" (pneuma). ${ }^{13}$ During the action of metallic conversion, Zosimus does not conceive of prime matter in an abstract way, since he identifies prime matter with black lead ( $\mu$ ó $\nu$ $\beta \delta$ o $\varsigma$ $\mu \varepsilon \lambda_{\alpha} \varsigma_{-}$-molubdos melas). ${ }^{14}$ With respect to the action of pneuma in Zosimus' alchemy, there are many references which are scattered all over his work. Zosimus discerns two kinds of action of pneuma, one active and volatile and one "static", meaning that it is in a state that allows for it to be collected. Regarding the first one, Zosimus equates sublimed vapours (aithalai) to pneuma, and he holds them responsible for the colouration of metals during their transformation. Specifically, in the chapter "On Those that Withstand and the Four Bodies According to Democritus", which belongs to Chapters to Eusebeia, he says:

For every sublimed vapour is pneuma and so [are] these qualities, the tingeing ones. And the divine Democritus speaks about whitening, and Hermes has spoken about smoke ( $\kappa \alpha \pi v o ́ \varsigma) .{ }^{15}$

Similarly, in another instance, in the Chapters to Eusebeia, Zosimus becomes more descriptive, and he provides us with more information on how these sublime vapours work. He explicitly states:

As cinnabar is boiled with species, it does not lose its pneuma; for as its pneuma is caused to run, that is cloud ( $\vee \varepsilon \varphi \varepsilon \hat{\lambda} \lambda)$ [is caused to run] by means of fire, and as cloud flees it gets captured by the bodies which are chasing it, and they are of the same nature with it, and most of all [it is captured] by tin. ${ }^{16}$

Concerning the second source, we see that Zosimus does not have a fixed terminology for connoting pneuma, since he uses the terms of sublimed vapour (aithale) and cloud (nefele) to denote the action of pneuma. Yet, what is interesting in the second source is that pneuma does not vanish during the conversion of metals, while at the same time it is also subjected to a kind of chase by the other bodies. This kind of airy pneuma, which is associated with the bestowal of qualities on metals, has strong ties with the pneumatic theory of the Stoic Chrysippus, while these connections have also been stressed in passing by Verbeke (Rinotas 2017, pp. 203-19; Verbeke 1945, pp. 338-48).

The second type of Zosimus' pneuma is static, and it is presented as the outcome of an alchemical procedure. This kind of pneuma, however, maintains its tingeing properties as the previous one, and it is meant for future use. In the fourth chapter of the Authentic Memoirs Zosimus describes the preparation of the "blond water", which involves the boiling of herbs; at the end of his recipe, he states:

And after you have taken the lid off you will find the herbs being consumed by fire but also having left their own tincture, that is, their own pneuma. ${ }^{17}$

Likewise, in the Chapters to Eusebeia, again where he discusses the "The Substrates and the four bodies", Zosimus gives us a similar account with respect to the static type of pneuma. He explicitly says:

And they [i.e., the bodies] throw off the useless [things] and turn [them] into vapour, and these useless things are called by other names after having been cleansed, and that is why they are blown [by bellows], and until the pure and tingeing part of theirs appears, they are burnt in the furnaces, and everything is blown within themselves so as to leave behind the useful and tingeing pneuma. ${ }^{18}$

As I have already mentioned, both sources indicate that pneuma can be a by-product of an alchemical procedure, which in turn simply aims at producing a moist-like pneuma that still has its tingeing properties, and can therefore be collected and used in future alchemical procedures. Pneuma's relation to moisture is indicated by two facts; in the first 
source Zosimus uses the word $\beta \alpha \dot{\alpha} \mu \alpha$ (bamma) which means "dye" or "tincture" but also "that in which a thing is dipped" and therefore it signifies a sort of moist-like material, which is used for tingeing purposes. Likewise, in the second source the verb $\dot{\xi} \xi \alpha \tau \mu i \zeta o v \sigma \iota$ (exatmizousi) refers to moist vapour too. At this point, it is worth examining one more source of Zosimus' work, which summarizes the role of pneuma in the conversion of metals. Specifically, at the beginning of the tenth chapter of the Authentic Memoirs, Zosimus says:

Rest of the waters, movement, increase, disembodiment, embodiment, extraction of pneuma from a body, tying of pneuma to a body, these are not [coming] from natures that are foreign or brought from outside; rather, the monospecific [monoeides] nature possesses the hard shells of the minerals as well as the humid pulp of the plants itself and only with respect to itself. ${ }^{19}$

According to Mertens, the first words of this source create allusions to laboratory workings and processes, while the ancient words of $\alpha \pi \sigma \sigma \omega \mu \dot{\alpha} \tau \omega \sigma \iota \zeta$ (aposômatôsis: disembodiment) and દ่ $\pi \iota \sigma \omega \mu \alpha \dot{\alpha} \omega \sigma \iota \varsigma$ (episômatôsis: embodiment) are used apax, that is, there is only one occurrence in the work of Zosimus. Yet, the expressions that follow render their meaning understandable, since aposômatôsis holds for the extraction of pneuma from a body and episômatôsis for the opposite action, that is the tying of pneuma to a body. ${ }^{20}$ That said, this source shows that Zosimus subscribes to the general alchemical theory of metallic conversion that we saw earlier and according to which there is usually a fixed body which becomes qualified by means of a volatile agent, that is, in the case of Zosimus, pneuma. Yet, the Zosimean volatile agent is mostly responsible for bestowing colour qualities on metals, while it can be also found in a moist-like form, i.e., a tincture. Finally, if we were to describe the Zosimean alchemical theory of conversion of metals in simple terms, that would be through the terms of aposômatôsis and episômatôsis, which denote the extraction from and the tying with the body, respectively.

\section{Spiritual Conversion in Zosimus of Panopolis' Work}

Spiritual conversion in Zosimus is linked to Gnostic and Hermetic ideas, which both seem to coexist simultaneously in the chapters of his corpus that are of a more "spiritual" character. $^{21}$ This should not come as a surprise to us since Panopolis, the birthplace of Zosimus, was close to Nag Hammadi, which in turn was a hub of Gnostic and Hermetic ideas. However, in this chapter, I will take a Gnostic approach to the Zosimean sources because this better serves the purposes of my study in the next chapter.

Concerning Gnosticism and Gnosis, there is an ongoing debate with respect to its terminology. While the term Gnosticism is usually used to denote the religious-philosophical system which was developed during the second and third centuries AD, the term Gnosis and Gnostic have adopted a more "perennial" meaning, since they are used for all ideas and systems, from antiquity to modern times, and they signify the esoteric knowledge which is needed in order to liberate and redeem oneself (Van den Broeck 2005, pp. 403-5). ${ }^{22}$ This Gnosis, which tends to liberate oneself from the fetters of matter, is also found in Graeco-Egyptian alchemy, and, in this regard, scholarly attempts which aimed at shedding light on their relation have been made from an early point (Sheppard 1957, pp. 86-101; Charron 2005, pp. 438-56).

The Gnostic idea of the necessity of a spiritual knowledge, which leads to salvation and redemption, is also found in Zosimus, and thus his religiously oriented alchemy has also been called "sacred technology" (Fraser 2007, p. 40). A consequence of this redemptive knowledge is the awakening of the "divine spark" that exists within us, which will help us return to approach the divine. According to the Gnostics, there is a "divine spark" in us, which is often designated as pneuma and "which has proceeded from the divine world and has fallen into this world of destiny, birth and death and which must be reawakened through its own divine counterpart in order to be finally restored" (Rudolph 1987, p. 57). An analogous idea is also found in Zosimus' Final Count where, as he addresses Theosebeia, he says: 
Sit calmly at home, and God, who is everywhere, and not confined in the smallest place like the daemons, will come to you. And, being calm in body, calm also your passions, desire and pleasure and anger and grief and the twelve portions of death. In this way, taking control of yourself, you will summon the divine [to come] to you, and truly it will come, that which is everywhere and nowhere. ${ }^{23}$

This text echoes the Gnostic doctrine of the "divine spark" since Zosimus urges Theosebeia to prepare herself mentally to receive the divine element within her. This preparation involves ethical connotations since Theosebeia must control herself and appease her passions. This instigation from Zosimus' part towards Theosebeia suggests a spiritual conversion that must take place before or during any practical alchemical procedure. Zosimus clearly alludes to the restoration of the "divine spark," that is, the divine pneuma as a necessary prerequisite, which, once it is restored, will aid the practical aspects of alchemy. The aforementioned is confirmed at the end of the Final Count, where Zosimus states:

So doing, you will attain the true and natural [tinctures] that are appropriate to certain times. Perform these things until your soul is perfected. When you realize that you have been perfected, and have found the natural [tinctures], spit on matter and, hastening towards Poimenandres [sic] and receiving baptism in the mixing-bowl, hasten up towards your own race. ${ }^{24}$

By this source, Zosimus ascertains that the aforementioned mental preparation by means of restoration of the divine spark (pneuma) is strictly connected with the alchemical procedures, therefore, by doing so Theosebeia will be able to "attain the true and natural tinctures." However, one may notice that both sources do not have any reference to pneuma, something which is essential for the understanding of our sources since divine spark is designated as pneuma in the Gnostic literature. In this regard, I follow Mertens' interpretation, who deems that both sources allude to the "awakening of the divine spark" and the pneumatization of man (Mertens 2002, p. 168). This expression echoes Zosimus' pneumatic man who is imprisoned in his Adamic body, and he should remove the latter in order to receive redemption. That said, by receiving the divine, one "awakens" the pneumatic man that exists within him and therefore Mertens' term of pneumatization becomes clearer since man "awakens" his pneumatic part. Furthermore, another indication that Zosimus refers to pneuma is his use of the word soul. Particularly, Mertens has shown that in Zosimus' texts there is little difference when he uses the terms soul and pneuma, while there are instances where the two words are used in very close connection. ${ }^{25}$ For example, in the chapter of On Sublimed Vapours, Zosimus says:

In this way, the spirits become bodies and the dead bodies become ensouled after having re-introduced in them the soul which comes from them. ${ }^{26}$

According to this source, Zosimus draws a close connection between soul and pneuma since bodies or metals seem to presuppose the action of pneuma in order to become ensouled. Turning back to our last source, when Zosimus instructs Theosebeia that she should "perform these things until her soul is perfected", it would not be perilous to surmise that with the word "soul", Zosimus might also refer to or at least imply pneuma too.

To this point I want to propose a new reading on this last source we encountered at the end of the Final Count. As we have already seen in the previous chapter, Zosimus talks about a "static," moist-like, pneuma which is usually left as a residue after some alchemical procedures, and needs to be collected. The expressions that he uses are the "tingeing pneuma" ( $\beta \alpha \pi \tau \iota k o ́ v \pi v \varepsilon \tilde{u} \mu \alpha$-baptikon pneuma) and "dye" ( $\beta \alpha \mu \mu \alpha$-bamma), which the latter also means "that in which something is dipped." 27 All the words (baptikon-bamma) that Zosimus uses to signify and describe the properties of pneuma are derived from the ancient Greek verb $\beta \alpha \dot{\alpha} \tau \omega$ (baptô), which means to dye or dip into a dye. Turning back to our source, the word which is used to signify the tinctures is $\beta \alpha \varphi \alpha i$ (baphai). Provided that all these words are interrelated with each other, then we are in a place to surmise that these "natural and true" tinctures may also involve the collection of the "tingeing pneuma." This interpretation is further strengthened by two more things: firstly, according to Zosimus, 
one should first restore the "divine spark" (pneuma) in order to be able to attain the "true tinctures." The same message is also conveyed in another Zosimean excerpt, the On the Bodies that Withstand and the Four Bodies According to Democritus, where he says:

This is the useful thing, the tingeing [pneuma]; such a man should be of subtle mind so as to understand the pneuma which comes out of the body and use it, and, after having preserved it, he will succeed in his purpose. ${ }^{28}$

Through this source, Zosimus is in accordance with what we saw in the source of the Final Count since one must be of a "subtle intelligence" or of a "refined mind" to understand and use the "tingeing pneuma," something which also suggests a mental preparation or at least a proper mental state, which would allow one to recognize the pneuma which comes out of the bodies. Yet, in our initial source, Zosimus urges Theosebeia to control her passions in order to perfect her soul and therefore it is the soul that gets involved in the process rather than the mind. This seemingly apparent contradiction gets resolved if we take into account Mertens' remarks, according to which Zosimus seems to equate soul to mind in his work. ${ }^{29}$ In this regard, one could interpret the expression of "subtle or refined mind" also as "subtle or refined soul" and thus a closer connection between the two sources is created. Specifically, one should be of "subtle soul" in order to understand the tingeing pneuma which comes out of bodies during the alchemical procedures and thus a certain preparation of the soul is presupposed if one wants to recognize and collect the pneuma of the alchemical procedures. Secondly, we have already seen that Zosimus uses a similar adjective to denote the meaning of "true" in reference to "tingeing pneuma." In

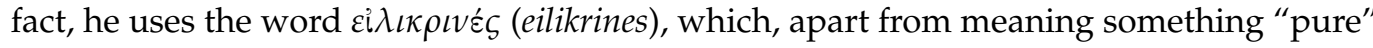
and "unmixed", also connotes "sincerity" and thus is close to Zosimus' expression of true tinctures. Taking all the previously outlined into account, my interpretation would run as follows: provided that the alchemist has restored the "divine spark," that is, the pneuma within him, then he will be in a position to attain the true tinctures, that is, the true "tingeing pneuma", which exists in the material realm of alchemy, and, after having attained both kinds of pneuma, then his or her soul will be perfected, and he or she will be able to able to receive the "spiritual baptism" that will allow him or her in turn to join "their race." Thus, material and spiritual alchemy are united in Zosimus' work by means of pneuma.

The last part of the Zosimean source alludes to the Gnostic myth of the Pneumatic man to which we referred briefly before and with which he deals in his Letter Omega. ${ }^{30}$ According to the Valentinians and general Gnostic anthropology, humans are divided into three categories: Pneumatics, Psychics, and Hylics or Choics. The Pneumatic men are the true Gnostics, and they can receive redemption either by exercising their mind or by receiving enlightenment through a divine saviour (Rudolph 1987, pp. 91-92; van den Broek 2013, p. 184). Similar ideas are met in Zosimus' Letter Omega, in which he refers to the myth of the primordial man who has many influences from the Valentinians and the Gnostic Apocryphon of John. Particularly, Zosimus aims at removing the fetters of Fate and thus he employs the aforementioned myth in order to explain humans' current situation. As Zosimus says:

So, then, the Adam of flesh is called Thouth with respect to the outer mould, but the man within him, the man of spirit ( $\pi v \varepsilon \mathcal{\varepsilon} \mu \alpha \tau \iota \kappa o ́ \varsigma)$ has a proper name as well as a common one ... But his common name is Phos $(\Phi \omega \zeta)$, and from this it followed that the men came to be known as Photes $(\varphi \tilde{\omega} \tau \alpha \varsigma) .{ }^{31}$

So according to Zosimus, the primordial man is characterized by a two-fold "nature" since he is composed of an outer mould, which is called the "Adam of flesh". and of an inner man, the "spiritual" or "pneumatic" man, who is called "Light." As Mertens informs us, both terms of "inner man" and of "pneumatic man" are found in the Gnostic literature, since the passage of the Republic that exists in the VI codex of the Nag Hammadi library has references to the "inner man," and the work of Irenaeus refers to the Gnostic "pneumatic man" too. ${ }^{32}$ Additionally, in this excerpt, Zosimus plays with the meaning of the word phos in ancient Greek, since its variant of $\varphi \omega \omega_{\zeta}$ means man and it is of Homeric origin and 
its variant of $\varphi \widetilde{\omega} \zeta$ means light. Thus, with the use of the word phos, Zosimus alludes to both the Adamic and Pneumatic nature of man. ${ }^{33} \mathrm{~A}$ bit further, Zosimus explains how the pneumatic man got imprisoned in his Adamic body and he says:

When Phos was in Paradise and being permeated by Fate, they persuaded him as he was innocent and unactivated to clothe himself with their Adam, who comes from Fate, who comes from the four elements. ${ }^{34}$

Zosimus goes on with his narrative by saying that man will be able to remove his corporeal fetters thanks to the help of Jesus Christ, and therefore he will also be able to fight

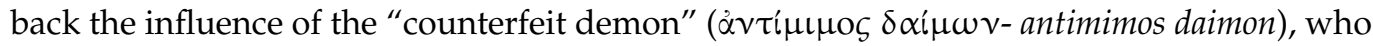
in turn holds him back from redeeming himself. Once again, Mertens has spotted all the Gnostic influences which permeate Zosimus' narrative, since such topics as the existence of Phos in Paradise, the Adamic Man and his fall, the picture of Jesus Christ as a redeemer and the notion of the "counterfeit demon" are subjects which are also found within the Gnostic literature. ${ }^{35}$ In fact, with respect to the "counterfeit demon," Stroumsa proposes an interpretation which is closer to Gnosticism and pneuma since he identifies "the counterfeit

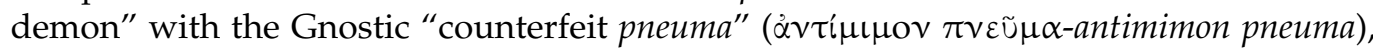
which is found in the Gnostic texts of Apocryphon of John and of Pistis Sophia. According to Stroumsa, this "counterfeit pneuma" is identified with Yaldabaoth, the leader of the archons, who as a malevolent and "counterfeit spirit" is opposed to man's redemption and salvation (Stroumsa 1984, pp. 142-43).

\section{Divine Water, Pneuma, and Gnosticism in Zosimus of Panopolis' Alchemy}

Thus far we have seen the notion of pneuma in both material and spiritual conversion in the work of Zosimus of Panopolis. In this chapter, I will focus on the Zosimean notion of "divine water" and how it relates to Gnostic literature in terms of pneuma. In fact, this chapter should be considered a sequel of the studies to Charron-Painchaud and Viano, who have both contributed enormously to the subject. ${ }^{36}$ With respect to the Charron-Painchaud study, the two authors focus on the Coptic Gospel According to Philip and specifically on the excerpt of the Nag Hammadi Codex II (61, 12b-20a), which presents "God as a dyer." The two authors, after having philologically spoken about the aforementioned excerpt, proceed with an updated emendation and translation of it which runs as follows:

God is a dyer. As good dyes- they are called the true ones-, perish with the things dyed in them, so is it with those whom God has dyed. Since his dyes are immortal, they become immortal by means of the drugs prepared by him. God baptizes those he baptizes in water <and power>. (Charron and Painchaud 2001, p. 44)

The important thing here is that their addition of the expression "and power" is not to be found in other translations, while, as they say, it "is an allusive designation of Spirit (Pneuma)" (Charron and Painchaud 2001, p. 43). ${ }^{37}$ Consequently, the authors interpret the source in terms of a baptismal procedure, which connotes a transition or transformation from mortality to immortality, and at the end they make connections of this source with Graeco-Egyptian alchemy without, however, providing any close textual evidence. Their basic argument is based on the fact that the key idea which exists in the Coptic-Gnostic text, that is, transformation through colour dyeing, is abundantly met in the Graeco-Egyptian alchemical literature, while a second argument is concerned with the "permanent dyes" and the "distinction between quality and substance," which are met in both kinds of literature (Charron and Painchaud 2001, pp. 47-48).

Viano's study examines the question of dualism in the ancient Greek alchemy with a special focus on the fundamental principle of transmutation, that is, the "divine water", which is described as "one substance with two natures." Viano concludes that in ancient Greek alchemy, there is a "dualism which derives from a masked monism" since the active principle of transmutation (divine water), albeit considered as something different from matter, actually derives from matter (Viano 2015, pp. 322-23). At the end of her paper, 
Viano uses the Coptic-Gnostic source as a means to link the Zosimean-Gnostic dualism with the dualism which derives from a masked monism that she referred to before. Although Viano accepts that Zosimus' Gnostic ideas are concerned with the coupled body-spirit (sôma-pneuma), she does not examine what the implications of pneuma are both in the Coptic-Gnostic source and in Zosimus' notion of divine water (Viano 2015, pp. 323-24). In this regard, I will firstly attempt to examine what the role of pneuma is in Zosimus' texts that are concerned with the divine water, and then see how it relates to the Coptic-Gnostic source at hand.

In ancient Greek, the expression "divine water" has a double meaning since the adjective "theion" can be translated as either "divine" or "sulphourous." As Viano meticulously notes, Zosimus is aware of this two-fold meaning of the expression "divine water" as he states that the word "divine" is applied to the things that have a bottom-up movement, such as the sublimed vapours. ${ }^{38}$ With respect to divine water's function, it should be regarded as an active agent, which is responsible for the colouration of metals, their composition, dissolution, and other alchemical processes. Turning to the relation between divine water and pneuma, there are two sources in Zosimus work that shed some light on the matter. Particularly, in the fourth chapter of the Authentic Memoirs we saw a source according to which pneuma was presented as a "dye" or "tincture", which is left behind and could be collected. ${ }^{39}$ The sequel of this source runs as follows:

This [the pneuma] has the power and nature of the untouched divine water. If you immerse silver into boiling water it will be indelible. ${ }^{40}$

Through this passage, the first connection between pneuma and divine water is established, since the pneuma has the power and nature of the divine water which is untouched.

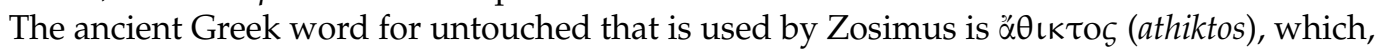
as Mertens admits, could have various meanings. The meaning that Mertens has adopted is associated with the fact that divine water is a liquid which is produced by an alembic, and therefore there was a moment according to when it was gaseous and evidently difficult to be touched. However, Mertens leaves an open window for another possibility. Particularly because the divine water is "divine," it should not be besmirched by touching it with bare hands. ${ }^{41}$ This last interpretation of Mertens leaves some space for associating athiktos with religious connotations, since "sacred" and "holy" are also other meanings of the ancient Greek word. The next sentence indicates that silver could become indelible if it will be immersed into boiling water, which is probably an allusion to the untouched divine water which was mentioned before. The important thing here is that this divine water can bring about a permanent and indelible dye and consequently this can also be achieved by pneuma, which has its power and nature. As a result, pneuma can bring about indelible tinctures or dyes, which in turn correspond to the "true and natural" tinctures that we saw in the previous chapter.

The second source clarifies even more the relation between pneuma and divine water. In particular, in the fifth chapter of the Authentic Memoirs, Zosimus gives an account on divine water, and says:

For [the Divine Water] is neither metal nor water which is always in motion nor [is it a] body for it does not hold of itself. This [the Divine Water] is the all in everything; for it has life and pneuma. ${ }^{42}$

A little before this source, Zosimus offered his account on the divine water, which he describes as a great mystery, the universal, and the hermaphrodite, etc. The important thing in our source is that the divine water has life and pneuma, and thus pneuma seems to be a part of the divine water or something that exists within it. Mertens interprets pneuma as the volatile part of the divine water without dealing with its tingeing properties. ${ }^{43}$ This raises the question of what is responsible for the colouration of metals, that is, the divine water as such, or the pneuma which exists within it. In my interpretation, it is due to pneuma that divine water is capable of bestowing colours on metals, and this is also justified by another source. In the Chapters to Eusebeia, Zosimus stresses that divine water can dye 
drugs, which, in turn, once they are dyed, can be capable of dyeing other things too. In this regard, this process seems to imply a transfer of pneumata, since divine water is transferring tingeing agents to drugs, and thus they come up with a property that they did not have before. $^{44}$

These last remarks concerning the relation between the divine water and pneuma could be proved useful to decipher the meaning of the Coptic-Gnostic source that we met before. First of all, it should be noted that there is no unanimously accepted translation for the Coptic-Gnostic source and therefore one should be cautious of its interpretation. In addition, one should be careful of the Gnostic connotations of the excerpt and particularly regarding what the notion of baptism is in the Gnostic milieu. Generally speaking, the baptism signifies for the Gnostics the purification of the soul from any material accretions in order for the soul to be able to attain spiritual perfection (Rudolph 1987, pp. 188-89; Fraser 2007, p. 46). According to the Valentinians, whose account is close to the one we meet in our source,

the baptism of the gnostic is an act which imparts to him the spirit (pneuma) of immortality, redemption and resurrection and thereby makes him a pneumatic. In baptism the gnostic obtains his immortal garment or the "perfect man". (Rudolph 1987, p. 227)

That said, I think we should see the act of baptism not only as a transformation from mortality to immortality, as suggested by Charron-Painchaud, but also as a transition from imperfection to perfection or-in Gnostic terms-from the non-Pneumatic to the Pneumatic state of man. To succeed in that, God, as a dyer, needs to have the appropriate means so as to lead man towards pneumatization. As we saw in Zosimus before, the alchemical pneuma has the "power" to create indelible tinctures that can also be construed as immortal, while, in Zosimean alchemy, pneuma as a "tingeing spirit" is the bearer of qualities of colours. That said, the Zosimean alchemy offers an interpretative scheme to explain the "immortal dyes of the God" since Zosimean dyes can be regarded as bearers of pneumatic agents, which can render things indelible or imperishable and bestow colour on them. Consequently, God makes the people he dyes immortal by means of the drugs he prepares for them. I deem that the word "drug" here, which is equivalent to the ancient Greek word $\varphi \alpha$ a $\rho \alpha \kappa o v$ (pharmakon), can be translated as tincture too, an option which has been adopted by Rudolph too (Rudolph 1987, p. 228). I prefer this translation because tincture implies on the one hand the presence of the "tingeing pneuma" which-in Gnostic terms-will contribute to the "pneumatization" of man, and on the other, because the last sentence suggests how these tinctures can be applied to men in order to become perfected. As we have already seen in Zosimus, the divine water has pneuma, and this Zosimean conception of the divine water fits well with the meaning of the last sentence of the Coptic-Gnostic source, since men are baptized or dipped into water and power. As Charron-Painchaud informs us, this "power" is an allusive designation of the Spirit, and thus it resembles the Zosimean pneumatic divine water.

In this way the baptismal act becomes analogous to the act of immersing metals into divine water. The "imperfect" Gnostic acts as an imperfect metal, and both become immersed into the "divine waters", which, by means of pneuma, will bring about an indelible perfection to both of them. Thus, the Gnostic arises with the immortal "colour" of the pneumatic man, and the imperfect metal with the irrevocable "colour" of silver or gold (see also Fraser 2007, p. 39).

\section{Conclusions}

This paper examined the notions of material and spiritual conversion in the work of Zosimus of Panopolis and how they relate and interact with his notion of pneuma. The material aspect of Zosimus' conversion is concerned with his alchemy, where pneuma seems to play an integral role as a bearer of qualities of colours and thus pneuma acts as an active principle on the metallic bodies. Likewise, pneuma is also met in the Gnostic ideas of Zosimus, which are connected to the spiritual conversion of man. In fact, Zosimus 
in his Final Count refers to a mental preparation, which echoes the Gnostic idea of the awakening of the "divine spark (рпеита)" and seems to be a prerequisite for the spiritual conversion and perfection of the soul of the alchemist. This awakening from the alchemist's part signifies that he or she will be able to also attain the "true and natural tinctures," which in turn seem to be connected with his notion of "tingeing spirit." Finally, the relation of Zosimean pneuma with the divine water can serve as an exegetical tool to interpret the Coptic-Gnostic source of the Gospel According to Philip, and thus we can infer that Zosimus' pneuma could be regarded as a "bridge term", which may offer us insight and interpretational tools not only for themes that are strictly found in the Zosimean corpus, but also for others that are external to it in terms of how it relates to other sources.

Funding: This research received no external funding.

Institutional Review Board Statement: Not applicable.

Informed Consent Statement: Not applicable.

Data Availability Statement: Not applicable.

Conflicts of Interest: The author declares no conflict of interest.

\section{Notes}

1 With respect to the name of alchemy, see (Halleux 1979, pp. 45-46; Cheak 2013, pp. 44-91; Lindsay 1970, pp. 68-89; Von Lippmann [1919] 1978, pp. 293-314).

2 Recently Roberts (2019) and Grimes (2018) have connected Zosimean alchemy with Egyptian lore and ritual. However, both books do not take the technical parts of Zosimus' alchemy into consideration.

3 For more on the subject see: (Keyser 1990, pp. 353-58; Luck [1985] 2006, pp. 435-38; Weyer 1998, pp. 22-23; Lindsay 1970, pp. 212-39).

4 For Zosimus' spiritual alchemy see: (Fowden 1993, pp. 120-26; Mertens 2002, pp. 165-75; Stolzenberg 1999, pp. 3-31; Fraser 2004, pp. 125-47; Fraser 2007, pp. 33-54).

5 Fraser (2007) has dealt with the notion of "baptism" in Zosimus' work and he has shown the Hermetic and Gnostic influences on the topic. However, in his study he has not dealt with pneuma and its two aspects (religious-technical) in the work of Zosimus and how it relates to "alchemical baptism".

6 (Charron and Painchaud 2001, pp. 41-50; Viano 2015). I would like to thank M. Mertens for bringing Viano's paper to my attention.

7 I take the term "material conversion" in a general and loose sense. I mostly mean a change in matter without laying a focus on the question of whether we have an actual transmutation. I treat the question of transmutation in Zosimus' work elsewhere.

8 Some of the Zosimean texts which are lost are: Things Wrought by Hand, According to Action, Letter Kappa, Letter Sigma, On the Intensity of Fire, and the Book of Keys. George Synkellos mentions Imouth as a work of Zosimos, whereas Suida speaks of twenty-eight books written by Zosimus and designated by the letters of the Greek alphabet. It also mentions a Life of Plato which is also lost. (Mertens 2008, p. 406).

9 There are two critical editions on the work of Zosimus: M. Berthelot and C. E. Ruelle, Collection des anciens Alchimistes Grecs vol. II (Berthelot and Ruelle 1888), (hereafter CAAG) and M. Mertens, Les alchimistes grecs: Zosime de Panopolis, Mémoires Authentiques (Mertens 1995), (hereafter MA). However, it should be noted that the Berthelot edition is problematic, and it should be used with caution. With respect to the chapters of Zosimus' work, see: (Mertens 2006, pp. 205-30).

10 Recently, Dufault has argued that Theosebeia was a patroness and Zosimus a client scholar. For more, see: (Dufault 2019, pp. 118-41). With respect to Zosimus, Grimes has argued that Zosimus was connected to the "House of Light" and that he was a "prophet". This opinion has been challenged by Bull who claimed that Zosimus was part of a Hermetic ritual community. For more, see: (Grimes 2006, p. 37) and (Bull 2018, pp. 218-21 and 224).

11 CAAG II, 192 and 214.

12 For references of this theory to Pseudo-Democritus, see: (Martelli 2013, pp. 132-34 and 245).

13 (Principe 2013, p. 16). See also notes 15 and 16 for textual evidence with respect to Zosimus's distinction between "body" and "spirit".

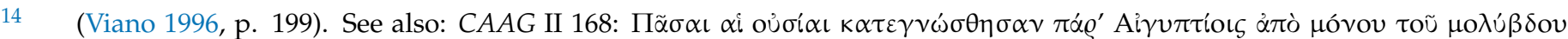

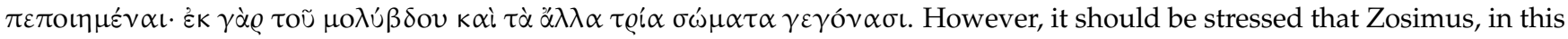
source, does not refer to prime matter per se, while he only refers to the three known bodies (iron, copper and tin) and not to gold and silver. I would like to thank Olivier Dufault for bringing this source into my attention. 


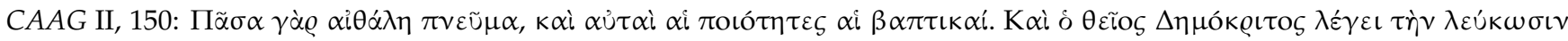

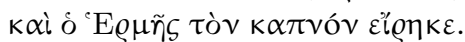

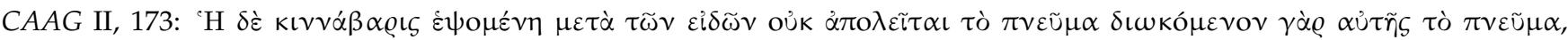

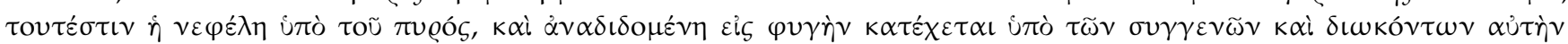

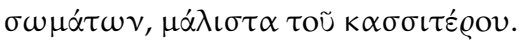

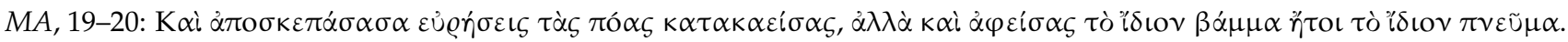

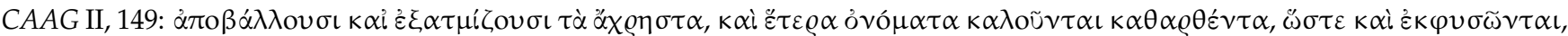

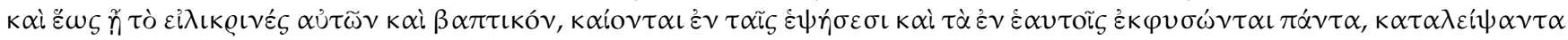

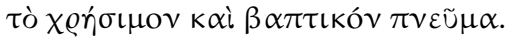

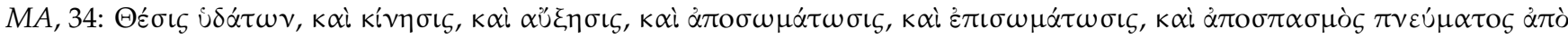

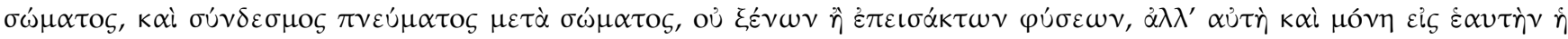

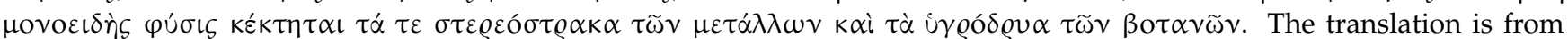
(Dufault 2015, p. 240).

For a Hermetic approach on the work of Zosimus, see (Festugière; 1944, pp. 238-47; Fowden 1993, pp. 120-26).

For the debate on Gnostic terminology, see (Williams 1996).

The ancient Greek text of the Final Count has been edited by (Festugière; 1944, p. 363). The translation is from (Fowden 1993, p. 122). Festugière; (1944, 367-68); the translation is from (Fowden 1993, pp. 122-23).

$M A, 215$.

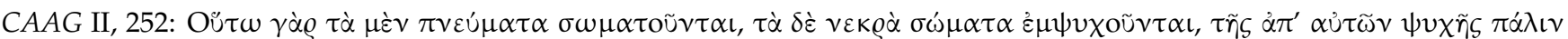

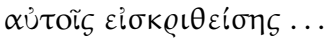

27 See notes 17 and 18.

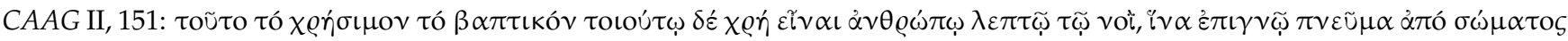

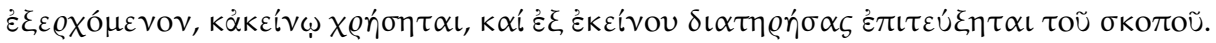
$M A, 75-6$.

The last source has also a Hermetic interpretation based on CH I (Poimandres) and CH IV. For more, see (Fowden 1993, pp. 120-26; Copenhaver 1992, pp. 1-7, 15-17, 93-124 and 131-38; Fraser 2007, pp. 43-45).

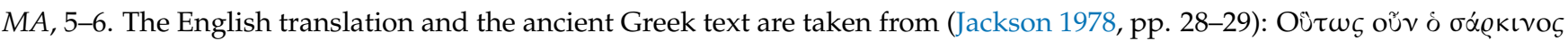

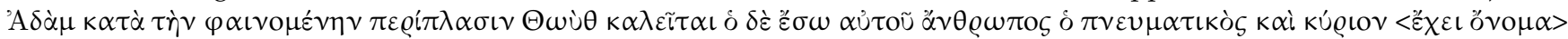

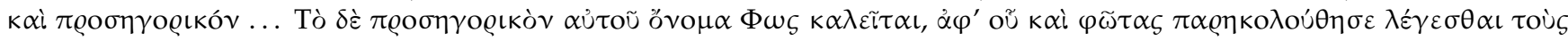
$\dot{\alpha} v \theta \varrho \dot{\omega} \pi \mathrm{ous}$.

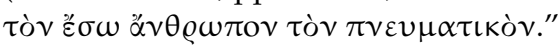
$M A, 94-6$.

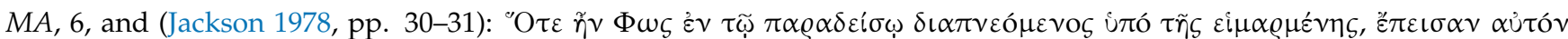

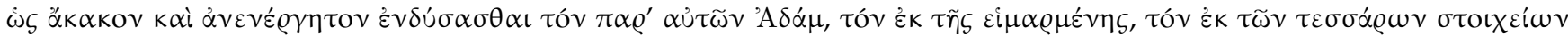
(English translation slightly modified). MA, 97-108.

See note 6.

For instance, the expression is omitted in the following translations: (Robinson 1981, p. 105; Layton 1987, p. 476).

CAAG II, 175; (Viano 2015, pp. 312-13).

See note 17 .

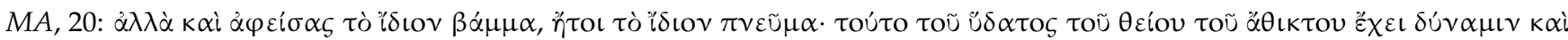

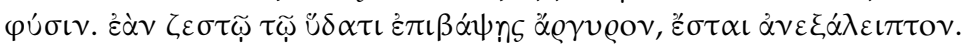

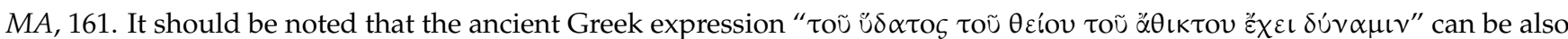
translated as "has the power/capacity of the water of untouched sulphur". For an interpretation with respect to the latter translation, see: (Martelli 2009, pp. 7-10).

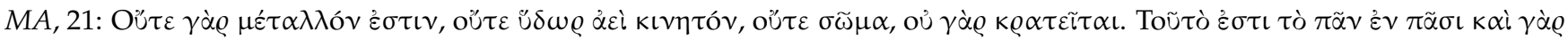

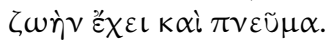

$43 \quad M A, 171$

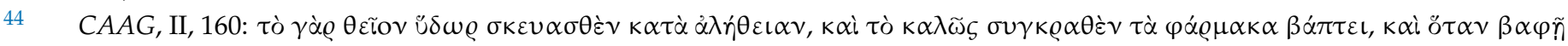

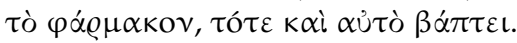




\section{References}

Berthelot, Marcellin, and Charles Emile Ruelle. 1888. Collection des Anciens Alchimistes Grecs Vol. II. Paris: G. Steinheil.

Bull, Christian. 2018. Hermes between Pagans and Christians: The Nag Hammadi Hermetica in Context. In The Nag Hammadi Codices and Late Antique Egypt. Edited by H. Lundhaug and L. Jenott. Tübingen: Mohr Siebeck, pp. 207-60.

Charron, Régine, and Louis Painchaud. 2001. God Is a Dyer. The Background and Significance of a Puzzling Motif in the Coptic Gospel According to Philip (CG II,3). Le Muséon 114: 41-50. [CrossRef]

Charron, Régine. 2005. The Apocryphon of John (NHC II, 1) and the Graeco-Egyptian Alchemical Literature. Vigiliae Christianae 59: 438-56. [CrossRef]

Cheak, Aaron. 2013. The Perfect Black: Egypt and Alchemy. In Alchemical Traditions: From Antiquity to the Avant-Garde. Edited by Aaron Cheak. Melbourne: Numen Books, pp. 44-91.

Copenhaver, Brian P. 1992. Hermetica: The Greek Corpus Hermeticum and the Latin Asclepius, New English Transl. with Notes and Introd. by Brian P. Copenhaver. Cambridge: University Press.

De Jong, Albert. 2006. Zosimus of Panopolis. In Dictionary of Gnosis and Western Esotericism. Edited by Wouter J. Hanegraaff. Leiden: Brill, pp. 1183-86.

Dodds, Eric Robertson. 1984. The Greeks and the Irrational. Berkeley: University of California Press.

Dufault, Olivier. 2015. Transmutation Theory in the Greek Alchemical Corpus. Ambix 62: 215-44. [CrossRef] [PubMed]

Dufault, Olivier. 2019. Early Greek Alchemy, Patronage and Innovation in Late Antiquity. Berkeley: Department of Classics, University of California.

Festugière;, André-Jean. 1944. La révélation d'Hermès Trismégiste. 1: L'astrologie et les sciences occultes, Par le R. P. Festugière; avec un appendice sur l'Hermétisme arabe par Louis Massignon. Etudes bibliques. Paris: Gabalda.

Fowden, Garth. 1993. The Egyptian Hermes: A Historical Approach to the Late Pagan Mind. Princeton: Princeton University Press.

Fraser, Kyle A. 2004. Zosimos of Panopolis and the Book of Enoch: Alchemy as Forbidden Knowledge. Aries 4: 125-47. [CrossRef]

Fraser, Kyle. 2007. Baptised in Gnosis: The spiritual alchemy of Zosimos of Panopolis. Dionysus 25: 33-54.

Fraser, Kyle. 2018. Distilling Nature's Secrets: The Sacred Art of Alchemy. In The Oxford Handbook of Science and Medicine in the Classical World. Edited by Paul Turquand Keyser and John Scarborough. New York: Oxford University Press, pp. 741-42.

Grimes, Shannon. 2018. Becoming Gold: Zosimos of Panopolis and the Alchemical Arts in Roman Egypt. Auckland: Rubedo Press.

Grimes, Shannon. 2006. Zosimus of Panopolis: Alchemy, Nature and Religion in Late Antiquity. Ph.D. dissertation, Syracuse University, Syracuse, NY, USA.

Halleux, Robert. 1979. Les Textes Alchimiques. Turnhout: Brepols.

Hopkins, Arthur John. 1934. Alchemy, Child of Greek Philosophy. New York: Columbia University Press.

Jackson, Howard. 1978. Zosimos of Panopolis on the Letter Omega. Montana: Scholars Press.

Keyser, Paul T. 1990. Alchemy in the Ancient World: From Science to Magic. Illinois Classical Studies 15: 353-78.

Layton, Bentley. 1987. The Gnostic Scriptures, A New Transl. with Annotations and Introductions by Bentley Layton. London: SCM.

Lindsay, Jack. 1970. The Origins of Alchemy in Graeco-Roman Egypt. London: Frederick Muller.

Luck, Georg. 2006. Arcana Mundi: Magic and the Occult in the Greek and Roman Worlds. Baltimore: The Johns Hopkins University Press. First published 1985.

Martelli, Matteo. 2009. "Divine Water" in the Alchemical Writings of Pseudo-Democritus. Ambix 56: 5-22. [CrossRef] [PubMed]

Martelli, Matteo. 2013. The Four Books of Pseudo-Democritus Sources of Alchemy and Chemistry: Sir Robert Mond Studies in the History of Early Chemistry. Leeds: Maney.

Martelli, Matteo. 2016. Graeco-Egyptian and Byzantine Alchemy. In A Companion to Science, Technology, and Medicine in Ancient Greece and Rome. Edited by Georgia L. Irby. Oxford and New York: WileyBlackwell, pp. 217-31.

Merianos, Gerasimos. 2017. Alchemy. In The Cambridge Intellectual History of Byzantium. Edited by Anthony Kaldellis and Nikitas Siniossoglou. Cambridge: Cambridge University Press, pp. 234-51.

Mertens, Michèle. 1995. Les alchimistes grecs: Zosime de Panopolis, Mémoires Authentiques. Paris: Les Belles Lettres.

Mertens, Michèle. 2002. Alchemy, Hermetism and Gnosticism at Panopolis c. 300 AD: The Evidence of Zosimus. In Perspectives in Panopolis; An Egyptian town from Alexander the Great to the Arab Conquest: Acts from an International Symposium Held in Leiden on 16-18 December 1998. Edited by Arno Egberts, Brian Paul Muhs and Joep Van der Vliet. Leiden: Brill, pp. 165-75.

Mertens, Michèle. 2006. Graeco-Egyptian Alchemy in Byzantium. In The Occult Sciences in Byzantium. Edited by Paul Magdalino and Maria Mavroudi. Geneva: La Pomme d'or, pp. 205-30.

Mertens, Michèle. 2008. Zosimos of Panopolis. In New Dictionary of Scientific Biography. Edited by Noretta Koertge. Detroit: Charles Scribner's Sons, pp. 405-8.

Principe, Lawrence. 2013. The Secrets of Alchemy. Chicago: University of Chicago Press.

Rinotas, Athanasios. 2017. Stoicism and Alchemy in Late Antiquity: Zosimus and the Concept of Pneuma. Ambix 64: 203-19. [CrossRef] [PubMed]

Roberts, Alison. 2019. Hathor's Alchemy: The Ancient Roots of the Hermetic Art. East Sussex: Northgate Publishers.

Robinson, James M. 1981. The Nag Hammadi Library in English. San Francisco: Harper \& Row.

Rudolph, Kurt. 1987. Gnosis: The Nature and History of Gnosticism. Translated by Robert McLachlan. San Francisco: Harper and Row.

Saint Irenaeus. 1857. Libros Quinque Adversus Haereses. Edited by W. Harvey. Cambridge: Typis Academicis.

Sheppard, Harry J. 1957. Gnosticism and Alchemy. Ambix 6: 86-101. [CrossRef] 
Stolzenberg, Daniel. 1999. Unpropitious Tinctures. Alchemy, Astrology and Gnosis According to Zosimos of Panopolis. Archives Internationales D'Histoire Des Sciences 142: 3-31.

Stroumsa, Gedaliahu A. Guy. 1984. Another Seed: Studies in Gnostic Mythology. Leiden: Brill.

Van den Broeck, Roelof. 2005. Gnosticism I: Gnostic Religion. In Dictionary of Gnosis E Western Esotericism. Edited by Wouter J. Hanegraaff. Leiden: Brill, pp. 403-16.

van den Broek, Roelof. 2013. Gnostic Religion in Antiquity. Cambridge: University Press.

Verbeke, Gerard. 1945. L'évolution de la doctrine du pneuma: Du stö̈cisme à S. Augustin: étude philosophique. UCL. Bibliothèque de l'Institut supérieur de philosophie. Paris: Desclée de Brouwer.

Viano, Cristina. 1996. Aristote et l'alchimie grecque: La transmutation et le modèle aristotélicien entre théorie et pratique. Revue d'histoire des Sciences 49: 189-213. [CrossRef]

Viano, Cristina. 2015. Une Substance, Deux Natures: Les Alchimistes Grecs et Le Principe de La Transmutation. In Dualismes. Doctrines

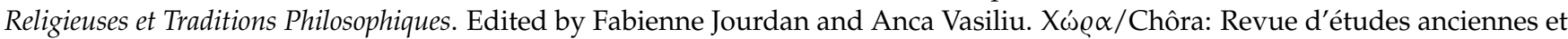
médiévales, vol. 13, pp. 309-25.

Von Lippmann, Otto. 1978. Entstehung und Ausbreitung der Alchemie. Hilesheim: Georg Olms Verlag. First published 1919.

Weyer, Jost. 1998. Antike Alchemie. In Alchemie: Lexicon einer hermetischen Wissenschaft. Edited by Claus Priesner und Karin Figala. München: Verlag C. H. Beck, pp. 22-25.

Williams, Michael Allen. 1996. Rethinking Gnosticism: An Argument for Dismantling a Dubious Category. Princeton: Princeton University Press. 